\title{
Gene networks related to the cell death elicited by hyperthermia in human oral squamous cell carcinoma HSC-3 cells
}

\author{
YOSHIAKI TABUCHI $^{1 *}$, SHIGEHITO WADA ${ }^{3 *}$, YUKIHIRO FURUSAWA $^{2}$, \\ KENZO OHTSUKA $^{4}$ and TAKASHI KONDO ${ }^{2}$ \\ ${ }^{1}$ Division of Molecular Genetics Research, Life Science Research Center, and Departments of ${ }^{2}$ Radiological Sciences, \\ ${ }^{3}$ Oral and Maxillofacial Surgery, Graduate School of Medicine and Pharmaceutical Sciences, University of \\ Toyama, Toyama 930-0194; ${ }^{4}$ Laboratory of Cell and Stress Biology, Department of \\ Environmental Biology, Chubu University, Kasugai 487-8501, Japan
}

Received October 18, 2011; Accepted November 24, 2011

DOI: $10.3892 /$ ijmm.2011.862

\begin{abstract}
Local hyperthermia (HT) for various types of malignant tumors has shown promising antitumor effects. To confirm the detailed molecular mechanism underlying cell death induced by HT, gene expression patterns and gene networks in human oral squamous cell carcinoma (OSCC) cells were examined using a combination of DNA microarray and bioinformatics tools. OSCC HSC-3 cells were treated with HT at $44^{\circ} \mathrm{C}$ for $90 \mathrm{~min}$ or mild hyperthermia (MHT) at $42^{\circ} \mathrm{C}$ for $90 \mathrm{~min}$, followed by culturing at $37^{\circ} \mathrm{C}$ for $0-24 \mathrm{~h}$. Treatment of cells with HT prevented cell proliferation $(62 \%)$ and induced cell death (17\%), whereas these alterations were not observed in cells treated with MHT. Microarray analysis revealed substantial differences with respect to gene expression patterns and biological function for the two different hyperthermic treatments. Moreover, we identified the temperature-specific gene networks $\mathrm{D}$ and $\mathrm{H}$ that were obtained from significantly
\end{abstract}

Correspondence to: Dr Yoshiaki Tabuchi, Division of Molecular Genetics Research, Life Science Research Center, University of Toyama, 2630 Sugitani, Toyama 930-0194, Japan

E-mail: ytabu@cts.u-toyama.ac.jp

*Contributed equally

Abbreviations: ATF3, activating transcription factor 3; BAG3, BCL2associated athanogene 3; CLU, clusterin; DNAJA1, DnaJ (Hsp40) homolog, subfamily A, member 1; DNAJB1, DnaJ (Hsp40) homolog, subfamily B, member 1; DUSP1, dual specificity phosphatase 1; GADD45B, growth arrest and DNA-damage-inducible, $\beta$; GAPDH, glyceraldehyde 3-phosphate dehydrogenase; HES1, hairy and enhancer of split 1, (Drosophila); HSPA1B, heat shock $70 \mathrm{kDa}$ protein 1B; HSPH1, heat shock 105/110 kDa protein 1; HSPs, heat shock proteins; HT, hyperthermia; JUN, jun proto-oncogene; MHT, mildhyperthermia; OSCC, oral squamous cell carcinoma; PGF, placental growth factor; PRKCD, protein kinase C, $\delta$; qPCR, quantitative polymerase chain reaction

Key words: hyperthermia, microarray, gene network, cell death, human oral squamous cell carcinoma HSC-3 up-regulated genes in the HT and MHT conditions, respectively, using Ingenuity pathway analysis tools. Gene network D, which contains 14 genes such as ATF3, DUSP1 and JUN, was associated with relevant biological functions including cell death and cellular movement. Gene network H, which contains 13 genes such as BAG3, DNAJB1 and HSPA1B, was associated with cellular function and maintenance and cellular assembly and organization. These findings provide a basis for understanding the detailed molecular mechanisms of cell death elicited by HT in human OSCC cells.

\section{Introduction}

In the treatment of oral squamous cell carcinoma (OSCC), treatment outcomes have improved in the past two decades due to progress in reconstructive techniques, stereotactic radiotherapy, new anticancer drugs such as taxanes, and combinations of these therapeutic modalities (1). Nonetheless, it is well known that patients with advanced tumors or tumor recurrence have a poor prognosis with a median survival period less than one year (2). Local hyperthermia (HT) for various malignant tumors including OSCC has been recognized as an effective and attractive tool with the advantages of relatively few side effects and slight damage to normal tissue. Combinations of HT with chemotherapy, radiotherapy or both have been clinically used for patients with cancer in various organs, and their antitumor effects have been verified by many clinical trials (3-7).

In general, HT elicits a wide spectrum of stress responses such as induction of heat shock proteins (HSPs), protein aggregation, an imbalance of protein homeostasis, DNA and RNA damage, reactive oxygen species production, cell growth arrest and cell death in mammalian cells $(8,9)$. In particular, HSPs, which are induced by heat, behave as molecular chaperones and exert strong cytoprotective effects that prevent cell death. The treatment of cells with HT induces numerous signal transduction pathways which contribute variously to cell death and survival (10-12). Although many biological processes are affected by HT, the overall responses to HT in mammalian cells remain unknown.

Recent DNA microarray and computational microarray analyzing technologies have provided a view of the expression 
profiles of many genes, and their relevant biological functions and gene networks based on the gene-expression profiles (13). To date, several investigators have demonstrated that geneexpression profiles, biological functions and gene networks in a wide variety of cell types are affected by mild hyperthermia (MHT) or HT (9,14-25).

It is well known that cancer cells exposed to HT of more than $42.5^{\circ} \mathrm{C}$ will undergo cell death, whereas exposure to MHT conditions, i.e., temperatures up to $42.5^{\circ} \mathrm{C}$, produces only slight or no cytotoxicity (26). The aim of this study was to better understand the detailed molecular mechanism by which HT induces cell death; thus, we compared the differences in the gene expression patterns of cells under HT conditions at $44^{\circ} \mathrm{C}$ (with cell death) and MHT conditions at $42^{\circ} \mathrm{C}$ (without cell death) using a combination of DNA microarray and bioinformatics tools.

\section{Materials and methods}

Cell culture. Human OSCC HSC-3 cells were obtained from the Human Science Research Resources Bank, Japan Health Sciences Foundation (Tokyo, Japan). The cells were cultured in E-MEM medium (Wako Pure Chemical Industries, Ltd., Osaka, Japan) supplemented with $10 \%$ fetal bovine serum at $37^{\circ} \mathrm{C}$ in humidified air with $5 \% \mathrm{CO}_{2}$ and $95 \%$ air.

MHT and HT treatments. MHT and HT were performed by immersing plastic vessels containing the attached cells in a water bath at $42^{\circ} \mathrm{C}\left( \pm 0.05^{\circ} \mathrm{C}\right)$ or $44^{\circ} \mathrm{C}\left( \pm 0.05^{\circ} \mathrm{C}\right)$ for $90 \mathrm{~min}$, respectively. The temperature was monitored with a digital thermometer (no. 7563, Yokogawa, Tokyo, Japan) during heating. After heat treatment, the cells were incubated for $0-24 \mathrm{~h}$ at $37^{\circ} \mathrm{C}$.

Analyses of cell growth and cell death. The number of cells was counted using a hemocytometer. For the detection of cell death, flow cytometry was used with propidium iodide and fluorescein isothiocyanate (FITC)-labeled Annexin V (Annexin V-FITC kit, Immunotech, Marseille, France) (27).

RNA isolation and gene expression analysis. Total-RNA was isolated from cells using an RNeasy total-RNA extraction kit (Qiagen, Valencia, CA, USA) according to the manufacturer's protocol. RNA samples were treated with RNase-free DNase I for $15 \mathrm{~min}$ at room temperature. Gene expression analysis was performed by a GeneChip ${ }^{\circledR}$ system with a Human Genome U133-plus 2.0 array, which was spotted with 54,675 probe sets (Affymetrix, Santa Clara, CA, USA) according to the manufacturer's instructions. Briefly, $500 \mathrm{ng}$ of total-RNA was used to synthesize cRNA with a GeneChip ${ }^{\circledR}$ 3' IVT Express kit (Affymetrix). After fragmentation, biotin-labeled cRNA was hybridized to the array at $45^{\circ} \mathrm{C}$ for $16 \mathrm{~h}$. The arrays were washed, stained with streptavidin-phycoerythrin, and scanned using a probe array scanner. The scanned arrays were analyzed using the GeneChip ${ }^{\circledR}$ Analysis Suite software (Affymetrix). The obtained hybridization intensity data were analyzed using the GeneSpring software (Silicon Genetics, Redwood City, CA, USA) to extract the significant genes. To examine gene ontology, including biological processes, cellular components, molecular functions, and gene networks, the obtained data were analyzed using the Ingenuity Pathway Analysis tools (Ingenuity Systems, Mountain View, CA, USA), a web-deliv- ered application that enables the identification, visualization, and exploration of molecular interaction networks in gene expression data (28).

Real-time quantitative polymerase chain reaction ( $q P C R$ ) assay. Real-time qPCR assay was performed on a real-time PCR system (Mx3000P, Stratagene Japan, Tokyo, Japan) using SYBR Premix Ex Taq II (Takara Bio, Shiga, Japan) or Premix Ex Taq (for the use of TaqMan probes; Takara Bio) according to the manufacturer's protocols. Reverse transcriptase reaction was carried out with total-RNA using an oligo(dt) primer and random hexamers. Real-time qPCR assay was performed using the specific primers listed in Table I. The transcript levels of these genes were estimated from the respective standard curves. Each expression level was normalized to the transcript level of glyceraldehyde 3-phosphate dehydrogenase (GAPDH) (21).

Statistical analysis. Data are shown as means \pm SD. The Student's t-test was used for statistical analysis and significance was assumed for P-values $<0.05$.

\section{Results}

Effects of MHT and HT on cell growth and cell death in OSCC HSC-3 cells. The cell number of HSC-3 cells after MHT or HT for 90 min followed by culture at $37^{\circ} \mathrm{C}$ for $24 \mathrm{~h}$ is shown in Fig. 1A. MHT at $42^{\circ} \mathrm{C}$ did not inhibit the growth of cells. On the other hand, significant growth inhibition was observed in cells treated with HT at $44^{\circ} \mathrm{C}$. The number of cells at $37^{\circ} \mathrm{C}$ (control), $42^{\circ} \mathrm{C}$ and $44^{\circ} \mathrm{C}$ were $20.8 \pm 2.0 \times 10^{4}, 19.6 \pm 2.6 \times 10^{4}$ and $7.9 \pm 1.7 \times 10^{4}$ cells (mean $\pm \mathrm{SD}$ ), respectively. Moreover, effects on cell death of MHT or HT for 90 min followed by culture at $37^{\circ} \mathrm{C}$ for different periods were examined. The control percentage of cell death was $3.1 \pm 1.0$ (mean \pm SD). Treatment by $\mathrm{MHT}$ at $42^{\circ} \mathrm{C}$ for $90 \mathrm{~min}$ did not change the percentage of cell death, the levels being 3.1 $\pm 2.2,3.1 \pm 1.2$ and $5.0 \pm 1.5$, (mean $\pm \mathrm{SD}$ ) for 0,6 and $12 \mathrm{~h}$, respectively. On the other hand, when HSC-3 cells were treated with $\mathrm{HT}$ at $44^{\circ} \mathrm{C}$ for $90 \mathrm{~min}$, cell death was significantly and time-dependently elevated, the levels being $4.4 \pm 1.0,9.5 \pm 0.9$ and $17.4 \pm 0.6$, (mean \pm SD) for 0 , 6 and $12 \mathrm{~h}$, respectively (Fig. 1B). The data indicate that either cell growth inhibition or cell death was observed only in cells treated with $\mathrm{HT}$ at $44^{\circ} \mathrm{C}$.

Global gene-expression analysis and identification of gene networks. In order to analyze gene-expression patterns of HSC-3 cells treated with HT, we compared the differences in the gene expression patterns of cells under HT conditions at $44^{\circ} \mathrm{C}$ (with cell death) and MHT conditions at $42^{\circ} \mathrm{C}$ (without cell death) using a GeneChip ${ }^{\circledR}$ system. Of the 54,675 probe sets analyzed, we identified the many probe sets that were differentially expressed by 2.0 -fold or more. We identified 443, 225 and 353 up-regulated and 784, 963 and 1,129 down-regulated probe sets at 0,6 and $12 \mathrm{~h}$ after MHT, respectively, and 344, 266 and 107 up-regulated and 580, 403 and 323 down-regulated probe sets at 0,6 and $12 \mathrm{~h}$ after HT, respectively (Table II). The complete list of probe sets from all samples is available on the Gene Expression Omnibus, a public database (http://www. ncbi.nlm.nih.gov/geo/query/acc.cgi?acc=GSE24783). 
Table I. Nucleotide sequences of primers and a TaqMan probe for target genes.

\begin{tabular}{lllc}
\hline Genes & Orientation & \multicolumn{1}{c}{ Nucleotide sequence (5' to 3') } & GenBank accession no. \\
\hline ATF3 & Sense & ACCTGACGCCCTTTGTCAAG & AB066566 \\
& Antisense & GGCACTTTGCAGCTGCAATC & \\
BAG3 & Sense & CGACCAGGCTACATTCCCAT & NM_004281 \\
& Antisense & TCTGGCTGAGTGGTTCTGG & \\
DNAJB1 & Sense & ACCCGGACAAGAACAAGGAG & NM_006145 \\
& Antisense & GCCACCGAAGAACTCAGCAA & \\
DUSP1 & Sense & GAGCTGTGCAGCAAACAGTC & NM_004417 \\
& Antisense & CAGGTACAGAAAGGGCAGGA & \\
GADD45B & Sense & CAGAAGATGCAGACGGTGAC & NM_015675 \\
& Antisense & ACCCGCACGATGTTGATGTC & NM_002046 \\
GAPDH & Sense & AAGGCTGGGGCTCATTTGCA & \\
& Antisense & ATGACCTTGCCCACAGCCTT & NM_005346 \\
HSPA1B & Sense & AGGTGCAGGTGAGCTACAAG & \\
& Antisense & ATGATCCGCAGCACGTTGAG & NM_006644 \\
HSPA1H & Sense & ACCATGCTGCTCCTTTCTCC & \\
& Antisense & CTGGGTTTCTGGTGGTCTC & J04111 \\
JUN & Sense & CTGCAAAGATGGAAACGACCTT & \\
& Antisense & TCAGGGTCATGCTCTGTTCAG & \\
& Probe & FAM-TATGACGATGCCCTCAACGCCTCGT-TAMRA &
\end{tabular}

ATF3, activating transcription factor 3; BAG3, BCL2-associated athanogene 3; DNAJB1, DnaJ (Hsp40) homolog, subfamily B, member 1; DUSP1, dual specificity phosphatase 1; GADD45B, growth arrest and DNA-damage-inducible, $\beta$; GAPDH, glyceraldehyde-3-phosphate dehydrogenase; HSPA1B, heat shock $70 \mathrm{kDa}$ protein 1B; HSPA1H, heat shock 105/110 kDa protein; JUN, jun proto-oncogene.
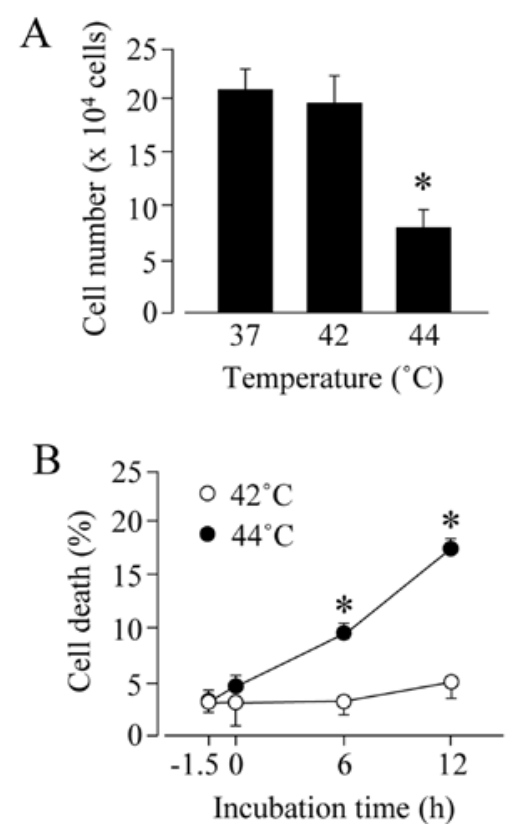

Figure 1. Effects of mild hyperthermia (MHT) and hyperthermia (HT) on cell growth and cell death in human OSCC HSC-3 cells. The cells were incubated at $37^{\circ} \mathrm{C}$ (control), $42^{\circ} \mathrm{C}(\mathrm{MTH})$ or $44^{\circ} \mathrm{C}(\mathrm{HT})$ for $90 \mathrm{~min}$ and then cultured at $37^{\circ} \mathrm{C}$ for $24 \mathrm{~h}$. (A) Cell numbers were counted. The cells were incubated at 42 or $44^{\circ} \mathrm{C}$ for $90 \mathrm{~min}$ and then cultured at $37^{\circ} \mathrm{C}$ for $12 \mathrm{~h}$. (B) Cell death was evaluated by flow cytometry using an Annexin V-FITC kit. Data are presented as means \pm SDs $(n=4)$. ${ }^{*} \mathrm{P}<0.05$ vs. control (cells treated at $\left.37^{\circ} \mathrm{C}\right) .{ }^{*} \mathrm{P}<0.05$ vs. control (non-treated cells).
We next carried out a functional category analysis of the probe sets at each time point using the Ingenuity Pathways Knowledge Base. The top biological functions at each time point and each condition are shown in Table II. In MHT-treated cells, the biological functions including cellular function and maintenance, and cellular growth and proliferation, or cell cycle and cellular development were observed in up- or downregulated probe sets, respectively. In HT-treated cells, the biological functions including gene expression and cell death, or post-transcriptional modification and gene expression were observed in up- or down-regulated probe sets, respectively. Moreover, two gene networks $\mathrm{D}$ and $\mathrm{H}$ were identified in the up-regulated probe sets affected by HT and MHT, respectively. Gene network D contained 14 up-regulated genes, such as activating transcription factor 3 (ATF3), dual specificity phosphatase 1 (DUSP1), growth arrest and DNA-damageinducible, $\beta$ (GADD45B), hairy and enhancer of split 1 , (Drosophila) (HES1), and jun proto-oncogene (JUN), and was associated with relevant biological functions including cell death (significance, 2.49E-10 to 1.57E-1) and cellular movement (2.3E-11 to 9.04E-4) (Fig. 2). Gene network H contained 13 up-regulated genes, such as BCL2-associated athanogene 3 (BAG3), DnaJ (Hsp40) homolog, subfamily B, member 1 (DNAJB1), heat shock $70 \mathrm{kDa}$ protein 1B (HSPA1B), and heat shock 105/110 kDa protein 1 (HSPH1), and was associated with relevant biological functions including cellular function and 


\section{Mild hyperthermia at $42^{\circ} \mathrm{C}$}

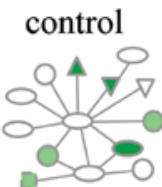

$0 \mathrm{~h}$

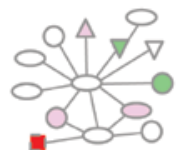

$6 \mathrm{~h}$

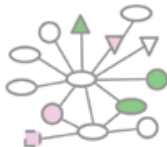

$12 \mathrm{~h}$

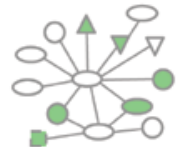

\section{Hyperthermia at $44^{\circ} \mathrm{C}$}

control

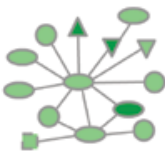

$0 \mathrm{~h}$

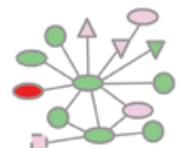

$6 \mathrm{~h}$

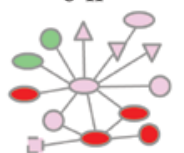

$12 \mathrm{~h}$

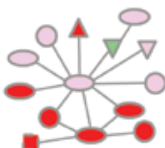

$44^{\circ} \mathrm{C}, 12 \mathrm{~h}$

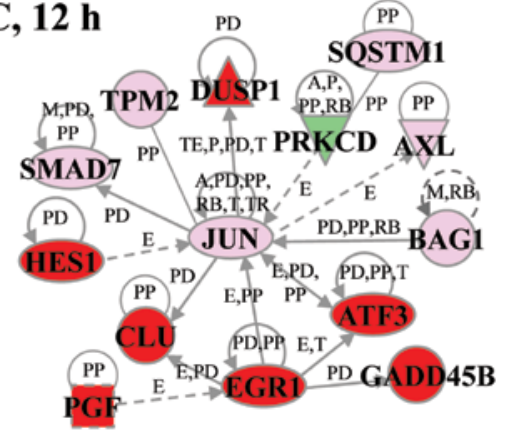

i. growth factor

$\nabla$ kinase

others

$\triangle$ phosphatase

transcription regulator

(A) B binding only

(A) $\rightarrow$ B acts on

direct interaction

------ indirect interaction

expession scale

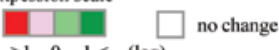

$>1 \quad 0 \quad-1<(\log )$

A, activation/deactivation

PD, protein-DNA binding

T, transcription

E, expression

PP, protein-protein binding

TR, translocation

M, biochemical modification

PR, protein-mRNA binding

P, phosphorylation/dephosphorylation

RB, regulation of binding

Figure 2. Gene network D. Up-regulated probe sets for the $\mathrm{HT}$ condition at $44^{\circ} \mathrm{C}$ (peak expression, 6 and/or $12 \mathrm{~h}$ ) were analyzed by the Ingenuity Pathways Analysis software. The network is shown graphically as nodes (genes) and edges (the biological relationships between the nodes).

\section{Mild hyperthermia at $42^{\circ} \mathrm{C}$}
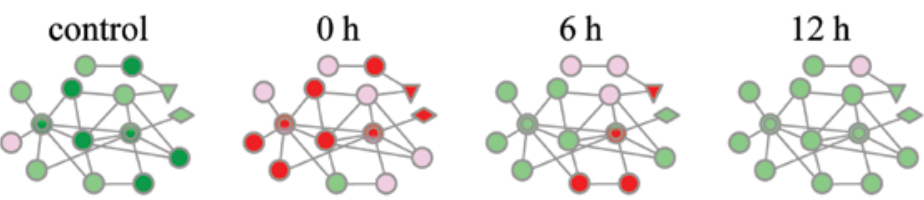

\section{Hyperthermia at $44^{\circ} \mathrm{C}$}
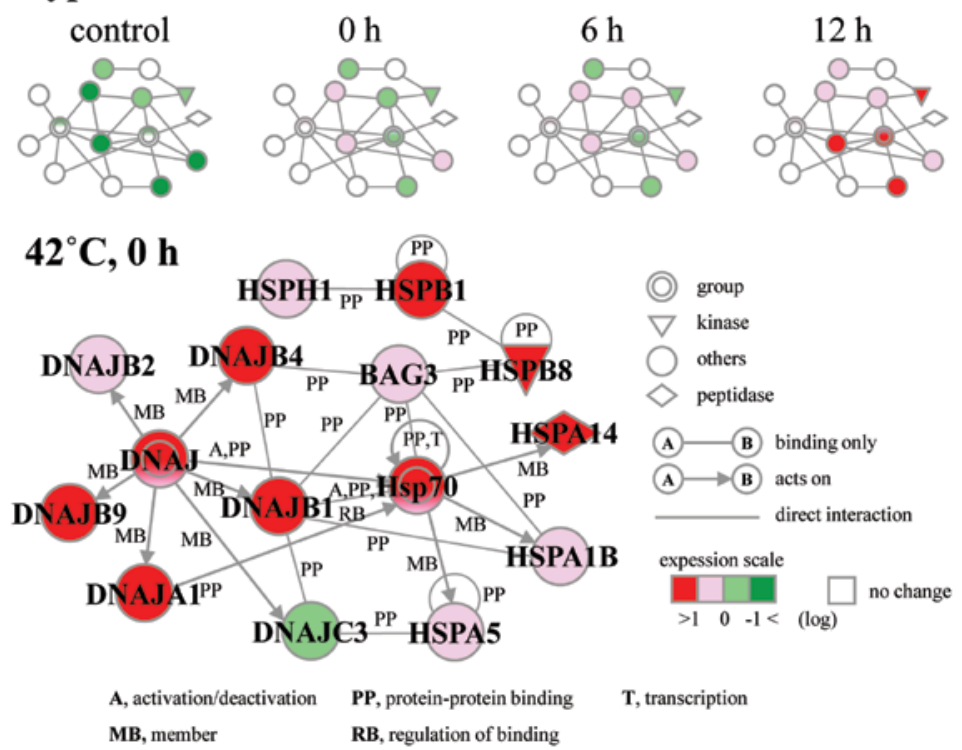

Figure 3. Gene network H. Up-regulated probe sets for the MHT condition (peak expression, 0 and/or 6 h) were analyzed by the Ingenuity Pathways Analysis software. The network is shown graphically as nodes (genes) and edges (the biological relationships between the nodes). 
Table II. Top biological functions.
Gene expression
Altered probe sets, $\mathrm{n}$
Functions probe sets

$\begin{array}{clll}\text { Heat stress at } 42^{\circ} \mathrm{C} & & \\ 0 \mathrm{~h} & \text { Up-regulation } & 443 & \text { Cellular functions and maintenance } \\ & \text { Down-regulation } & 784 & \text { Cell cycle } \\ 6 \mathrm{~h} & \text { Up-regulation } & 225 & \text { Cellular growth and proliferation } \\ & \text { Down-regulation } & 963 & \text { Cellular development } \\ 12 \mathrm{~h} & \text { Up-regulation } & 353 & \text { Cellular growth and proliferation } \\ & \text { Down-regulation } & 1,129 & \text { Cell cycle } \\ \text { Heat stress at } 44^{\circ} \mathrm{C} & & & \text { Gene expression } \\ 0 \mathrm{~h} & \text { Up-regulation } & 344 & \text { Post-transcriptional modification } \\ & \text { Down-regulation } & 580 & \text { Cell death } \\ 6 \mathrm{~h} & \text { Up-regulation } & 266 & \text { Gene expression } \\ & \text { Down-regulation } & 403 & \text { Cell death } \\ & \text { Up-regulation } & 107 & \text { Gene expression }\end{array}$

HSC- 3 cells were treated with heat stress at 42 or $44^{\circ} \mathrm{C}$ for $90 \mathrm{~min}$ and then cultured at $37^{\circ} \mathrm{C}$ for 0,6 or $12 \mathrm{~h}$. Gene expression was monitored using the GeneChip microarray system. Many probe sets were up- and down-regulated by more than 2-fold were identified. Functional category analysis was performed using the Ingenuity Pathways Knowledge Base. The top biological functions are shown.

maintenance (significance, $8.43 \mathrm{E}-14$ to $3.74 \mathrm{E}-2$ ) and cellular assembly and organization (9.31E-8 to $3.74 \mathrm{E}-2)$ (Fig. 3).

Verification of differentially expressed genes. To verify the microarray results, real-time qPCR was performed. The expression levels of eight selected genes were comparable to those determined by GeneChip ${ }^{\circledR}$ gene expression analysis. Among the genes in gene network $\mathrm{D}$, the expression levels of ATF3, DUSP1, GADD45B and JUN were markedly and time-dependently increased after HT-treatment. On the other hand, in MHT-treated cells, the expression levels of ATF3 and DUSP1 were transiently increased at time point $0 \mathrm{~h}$, and the levels of GADD45B and JUN did not increase over the culture period. Among the genes in gene network $\mathrm{H}$, the expression levels of BAG3, DNAJB1, HSPA1B and HSPH1 were transiently and significantly elevated at time point 0 and/or $3 \mathrm{~h}$ in MHT-treated cells. On the other hand, the expression levels of these 4 genes were gradually and significantly elevated when peaks were observed at the 12-h time point (Fig. 4).

\section{Discussion}

DNA microarray and computational data analysis technologies are powerful technologies for elucidating genome-wide gene expression signatures in various life science research areas (13). In the present study, a unique gene network for cell death elicited by HT treatment at $44^{\circ} \mathrm{C}$ in human OSCC cells was identified using these technologies. To our knowledge, this is the first report regarding the identification of gene networks influenced by HT in OSCC cells.

The temperature of $42.5^{\circ} \mathrm{C}$ for cancer cells is well known to be the inflection point of HT, that is, cancer cells exposed to temperatures $>42.5^{\circ} \mathrm{C}$ undergo cell death, but exposure of up to $42.5^{\circ} \mathrm{C}$ induces slight or no cytotoxicity (26). In the present study, the treatment of human OSCC HSC-3 cells with HT at $44^{\circ} \mathrm{C}$, higher than the inflection point, significantly induced cell death while treatment with $\mathrm{MHT}$ at $42^{\circ} \mathrm{C}$, lower than the inflection point, did not. These results were comparable to our previous studies using human leukemia U937 cells $(25,27)$. As expected, substantial differences with respect to gene expression patterns and biological functions between HT and MHT treatments were observed in HSC-3 cells. Furthermore, Ingenuity pathway analysis identified the significantly-altered and temperature-specific gene networks $\mathrm{D}$ and $\mathrm{H}$ that were obtained from up-regulated genes in HT- and MHT-treated cells, respectively. In addition, real-time qPCR assay demonstrated that the expression levels of eight selected genes were comparable to those detected by the microarray experiment. In this study, gene network H contained many HSPs such as DNAJA1, DNAJB1 and HSPA1B, and was mainly associated with the relevant biological function of cellular function and maintenance (Fig. 3). Microarray and real-time qPCR experiments clearly indicated that the up-regulation of HSPs in the MHT condition at $42^{\circ} \mathrm{C}$ occurred at earlier time points than those in the $\mathrm{HT}$ condition at $44^{\circ} \mathrm{C}$. Under MHT without cell death, early induction of HSPs may exert central cytoprotective effects that prevent cell death (10-12). HSPs including DNAJA1 (29), DNAJB1 (30) and HSPA1B (31), and BAG3 (32) have been previously described as anti-cell-death molecules. A previous report indicated that the specific protein interaction between BAG3 and Hsp70 occurred and that silencing of BAG3 attenuated apoptosis in the colonic cancer cell line RKO (32). It is also possible that HSPs may play a role in cytoprotection from HT-induced cell death at $44^{\circ} \mathrm{C}$. Induction of HSPs and/or BAG3 is a common response to heat with or without cell death, as described in several microarray studies (14-19,21-25). 

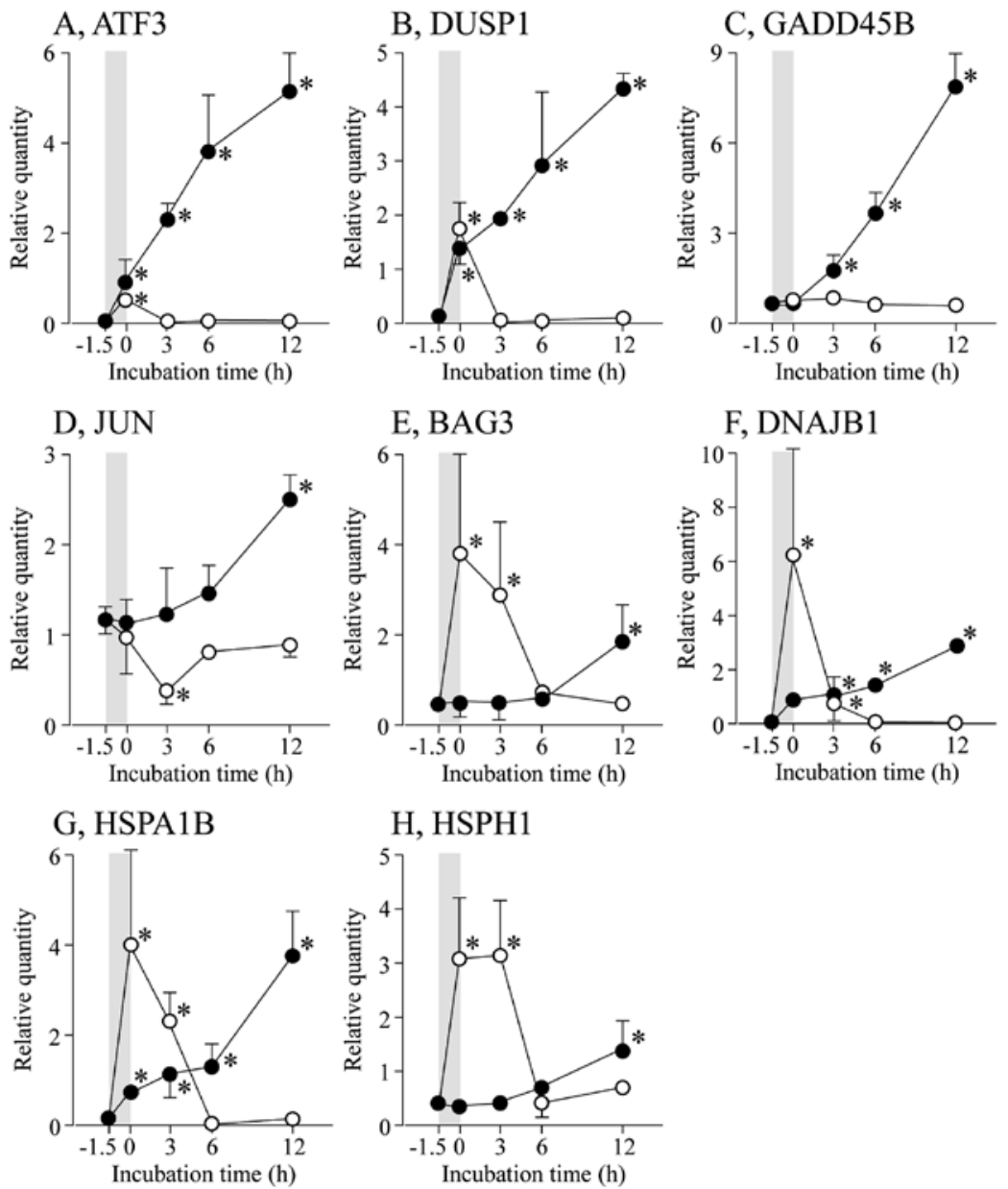

Figure 4. Verification of microarray results by real-time qPCR. HSC-3 cells were incubated at $42^{\circ} \mathrm{C}$ (mild hyperthermia, open circles) or $44^{\circ} \mathrm{C}$ (hyperthermia, closed circles) for $90 \mathrm{~min}$ and then cultured at $37^{\circ} \mathrm{C}$ for 0-12 h. Real-time qPCR was performed. (A) ATF3; (B) DUSP1; (C) GADD45B; (D) JUN; (E) BAG3; (F) DNAJB1; (G) HSPA1B; (H) HSPH1. Each expression level was normalized to the GAPDH expression level. The shadows indicate heat treatment. Data are presented as means \pm SDs $(n=4)$. ${ }^{*} \mathrm{P}<0.05$ vs. control (non-treated cells).

We successfully identified gene network D that was associated with relevant biological functions including cell death from up-regulated genes in the HT condition at $44^{\circ} \mathrm{C}$ (Fig. 2). The gene network D had JUN at the center and contained ATF3, DUSP1, HES1 and GADD45B. The up-regulation of almost all genes in network D was remarkable and was relatively sustained at the HT condition, whereas a transient and slight increase in the expression of several genes including ATF3, CLU (clusterin), DUSP1, PGF (placental growth factor), and PRKCD (protein kinase $C, \delta$ ) was detected only at the 0 - or 6-h time point at the MHT condition. It has been indicated that DUSP1 protein increases the death of Jurkat T cells (33). Kannan et al (34) recently demonstrated that Notch/HES1mediated poly (ADP-ribose) polymerase 1 activation leads to apoptosis in human precursor B-leukemia cell lines. It has also been reported that ectopic overexpression of GADD45B protein is apoptogenic in HeLa cells (35). JUN and ATF3, the basic-region leucine zipper transcription factors, have been reported to participate in cell death in human cell lines $(36,37)$. These cell death-associated genes in gene network D may be correlated with the cell death induced by HT in HSC-3 cells. In several microarray experiments, heat stress induced elevation of the expression of ATF3, DUSP1, GADD45B and JUN $(18,19,21,23-25)$.
In conclusion, the present results indicate that the differentially expressed genes and gene networks identified here are likely to be related to the cell death induced by HT in OSCC cells. HT in combination with other treatments has been considered a promising approach in cancer therapy (3-7). Thus, the current data will help enable the rational design of more effective strategies for future HT therapy in OSCC cells.

\section{Acknowledgements}

This study was supported in part by a Grant-in-Aid from the Japanese Ministry of Education, Culture, Sports, Science and Technology.

\section{References}

1. Scully C and Bagan JV: Recent advances in oral oncology 2008; squamous cell carcinoma imaging, treatment, prognostication and treatment outcomes. Oral Oncol 45: e25-e30, 2009.

2. Cruz JJ, Ocaña A, Navarro M, Barco ED and Fonseca E: New options in the treatment of locally advanced head and neck cancer: role for induction chemotherapy. Cancer Treat Rev 34: 268-274, 2008.

3. van der Zee J, González González D, van Rhoon GC, van Dijk JD, van Putten WL and Hart AA: Comparison of radiotherapy alone with radiotherapy plus hyperthermia in locally advanced pelvic tumours: a prospective, randomised, multicentre trial. Dutch Deep Hyperthermia Group. Lancet 355: 1119-1125, 2000. 
4. Harima Y, Nagata K, Harima Ostapenko VV, Tanaka Y and Sawada S: A randomized clinical trial of radiation therapy versus thermoradiotherapy in stage IIIB cervical carcinoma. Int J Hyperthermia 17: 97-105, 2001.

5. Xia H, Karasawa K, Hanyu N, Chang TC, Okamoto M, Kiguchi Y, Kawakami M and Itazawa T: Hyperthermia combined with intrathoracic chemotherapy and radiotherapy for malignant pleural mesothelioma. Int J Hyperthermia 22: 613-621, 2006.

6. Aktas M, de Jong D, Nuyttens JJ, van der Zee J, Wielheesen DH, Batman E, Burger CW and Ansink AC: Concomitant radiotherapy and hyperthermia for primary carcinoma of the vagina: a cohort study. Eur J Obstet Gynecol Reprod Biol 133: 100-104, 2007.

7. Van DerZee J, De Bruijne M, Mens JW, Ameziane A, BroekmeyerReurink MP, Drizdal T, Linthorst M and Van Rhoon GC: Reirradiation combined with hyperthermia in breast cancer recurrences: overview of experience in Erasmus MC. Int J Hyperthermia 26: 638-648, 2010.

8. Lindquist S: The heat-shock response. Annu Rev Biochem 55: 1151-1191, 1986

9. Richter K, Haslbeck M and Buchner J: The heat shock response: life on the verge of death. Mol Cell 40: 253-266, 2010.

10. Gabai VL, Yaglom JA, Volloch V, Meriin AB, Force T, Koutroumanis M, Massie B, Mosser DD and Sherman MY: Hsp72mediated suppression of c-Jun N-terminal kinase is implicated in development of tolerance to caspase-independent cell death. Mol Cell Biol 20: 6826-6836, 2000.

11. Verheij M, Bose R, Lin XH, Yao B, Jarvis WD, Grant S, Birrer MJ, Szabo E, Zon LI, Kyriakis JM, Haimovitz-Friedman A, Fuks Z and Kolesnick RN: Requirement for ceramide-initiated SAPK/ JNK signaling in stress-induced apoptosis. Nature 380: 75-79, 1996.

12. Woessmann W, Meng YH and Mivechi NF: An essential role for mitogen-activated protein kinases, ERKs, in preventing heatinduced cell death. J Cell Biochem 74: 648-662, 1999.

13. Werner T: Bioinformatics applications for pathway analysis of microarray data. Curr Opin Biotechnol 19: 50-54, 2008.

14. Schena M, Shalon D, Heller R, Chai A, Brown PO and Davis RW: Parallel human genome analysis: microarray-based expression monitoring of 1000 genes. Proc Natl Acad Sci USA 93: 10614-10619, 1996.

15. Dinh HK, Zhao B, Schuschereba ST, Merrill G and Bowman PD: Gene expression profiling of the response to thermal injury in human cells. Physiol Genomics 7: 3-13, 2001

16. Narita N, Noda I, Ohtsubo T, Fujieda S, Tokuriki M, Saito T and Saito H: Analysis of heat-shock related gene expression in headand-neck cancer using cDNA arrays. Int J Radiat Oncol Biol Phys 53: 190-196, 2002.

17. Sonna LA, Gaffin SL, Pratt RE, Cullivan ML, Angel KC and Lilly CM: Effect of acute heat shock on gene expression by human peripheral blood mononuclear cells. J Appl Physiol 92: 2208-2220, 2002.

18. Kato N, Kobayashi T and Honda H: Screening of stress enhancer based on analysis of gene expression profiles: enhancement of hyperthermia-induced tumor necrosis by an MMP-3 inhibitor. Cancer Sci 94: 644-649, 2003

19. Murray JI, Whitfield ML, Trinklein ND, Myers RM, Brown PO and Botstein D: Diverse and specific gene expression responses to stresses in cultured human cells. Mol Biol Cell 15: 2361-2374, 2004.

20. Yasumoto J, Kirita T, Takahashi A, Ohnishi K, Imai Y, Yuki K and Ohnishi T: Apoptosis-related gene expression after hyperthermia in human tongue squamous cell carcinoma cells harboring wild-type or mutated-type p53. Cancer Lett 204 41-51, 2004.

21. Wada S, Tabuchi Y, Kondo T, Cui ZG, Zhao QL, Takasaki I, Salunga TL, Ogawa R, Arai T, Makino K and Furuta I: Gene expression in enhanced apoptosis of human lymphoma U937 cells treated with the combination of different free radical generators and hyperthermia. Free Radic Res 41: 73-81, 2007.
22. Tabuchi Y, Takasaki I, Wada S, Zhao QL, Hori T, Nomura T, Ohtsuka K and Kondo T: Genes and genetic networks responsive to mild hyperthermia in human lymphoma U937 cells. Int J Hyperthermia 24: 613-622, 2008.

23. Borkamo ED, Dahl O, Bruland O and Fluge O: Global gene expression analyses reveal changes in biological processes after hyperthermia in a rat glioma model. Int J Hyperthermia 24: 425-441, 2008.

24. Furusawa Y, Tabuchi Y, Takasaki I, Wada S, Ohtsuka K and Kondo T: Gene networks involved in apoptosis induced by hyperthermia in human lymphoma U937 cells. Cell Biol Int 33: 1253-1262, 2009

25. Furusawa Y, Tabuchi Y, Wada S, Takasaki I, Ohtsuka K and Kondo T: Identification of biological functions and gene networks regulated by heat stress in U937 human lymphoma cells. Int J Mol Med 28: 143-151,2011.

26. Dewey WC, Hopwood LE, Sapareto SA and Gerweck LE: Cellular responses to combinations of hyperthermia and radiation. Radiology 123: 463-474, 1977.

27. Kameda K, Kondo T, Tanabe K, Zhao QL and Seto H: The role of intracellular $\mathrm{Ca}^{2+}$ in apoptosis induced by hyperthermia and its enhancement by verapamil in U937 cells. Int J Radiat Oncol Biol Phys 49: 1369-1379, 2001.

28. Tabuchi Y, Takasaki I, Doi T, Ishii Y, Sakai H and Kondo T: Genetic networks responsive to sodium butyrate in colonic epithelial cells. FEBS Lett 580: 3035-3041, 2006.

29. Tarlac V and Storey E: Role of proteolysis in polyglutamine disorders. J Neurosci Res 74: 406-416, 2003.

30. Zhou H, Li SH and Li XJ: Chaperone suppression of cellular toxicity of huntingtin is independent of polyglutamine aggregation. J Biol Chem 276: 48417-48424, 2001.

31. Daugaard M, Kirkegaard-Sørensen T, Ostenfeld MS, Aaboe M, Høyer-Hansen M, Orntoft TF, Rohde M and Jäättelä M: Lens epithelium-derived growth factor is an $\mathrm{Hsp} 70-2$ regulated guardian of lysosomal stability in human cancer. Cancer Res 67: 2559-2567, 2007.

32. Jacobs AT and Marnett LJ: HSF1-mediated BAG3 expression attenuates apoptosis in 4-hydroxynonenal-treated colon cancer cells via stabilization of anti-apoptotic Bcl-2 proteins. J Biol Chem 284: 9176-9183, 2009.

33. Matsuda S, Minowa A, Suzuki S and Koyasu S: Differential activation of c-Jun NH2-terminal kinase and p38 pathways during FTY720-induced apoptosis of T lymphocytes that is suppressed by the extracellular signal-regulated kinase pathway. J Immunol 162: 3321-3326, 1999.

34. Kannan S, Fang W, Song G, Mullighan CG, Hammitt R, McMurray J and Zweidler-McKay PA: Notch/HES1-mediated PARP1 activation: a cell type-specific mechanism for tumor suppression. Blood 117: 2891-2900, 2011.

35. Takekawa $M$ and Saito $H$ : A family of stress-inducible GADD45-like proteins mediate activation of the stress-responsive MTK1/MEKK4 MAPKKK. Cell 95: 521-530, 1998.

36. Holzberg D, Knight CG, Dittrich-Breiholz O, Schneider H, Dörrie A, Hoffmann E, Resch K and Kracht M: Disruption of the c-JUN-JNK complex by a cell-permeable peptide containing the c-JUN delta domain induces apoptosis and affects a distinct set of interleukin-1-induced inflammatory genes. J Biol Chem 278: 40213-40223, 2003.

37. Lee SH, Bahn JH, Whitlock NC and Baek SJ: Activating transcription factor 2 (ATF2) controls tolfenamic acid-induced ATF3 expression via MAP kinase pathways. Oncogene 29: 5182-5192, 2010. 